\title{
German Schools Abroad: Teachers' Views on Translanguaging and Emerging Research Perspectives on Children's Language Biographies and Educational Professionalization
}

\section{Julie A. Panagiotopoulou, Lisa Rosen, Jenna Strzykala, Janine Fißmer and Timo Neubert}

\section{Abstract}

In this chapter, we present three ongoing dissertation projects that emerged from the research project "migration-related multilingualism and educational professionalism" (led by Julie A. Panagiotopoulou and Lisa Rosen). The common ground of these projects is the focus on German schools abroad and the qualitative research approach to firstly, translingual practices and language ideologies, secondly, multilingual educational biographies of students, and thirdly, transnational professional biographies of teachers.

J. A. Panagiotopoulou $(\bowtie) \cdot$ L. Rosen · J. Strzykala $\cdot$ J. Fißmer $\cdot$ T. Neubert University of Cologne, Cologne, Germany

e-mail: a.panagiotopoulou@uni-koeln.de

L. Rosen

e-mail: lisa.rosen@uni-koeln.de

J. Strzykala

e-mail: jenna.strzykala@uni-koeln.de

J. Fißmer

e-mail: jfissme1@uni-koeln.de

T. Neubert

e-mail: timo.neubert@uni-koeln.de

(C) The Author(s) 2020

J. A. Panagiotopoulou et al. (eds.), Inclusion, Education and

Translanguaging, Inklusion und Bildung in Migrationsgesellschaften,

https://doi.org/10.1007/978-3-658-28128-1_11 


\section{Keywords}

Translanguaging · Inclusion/exclusion · German schools abroad - Language biographies $\cdot$ Educational professionalization

\section{Introduction}

In this chapter, we present research projects on German schools abroad. After introducing the initial project "migration-related multilingualism and educational professionalism" (see Sect. 2.1), we outline Jenna Strzykala's doctoral research, which focuses on the views of teachers working at German schools abroad in North America-specifically Boston and Montreal (Sect. 2.2). Rather than discussing desiderata in the following, we present two new projects that have emerged from the initial project (see Sect. 3). We therefore refrain from drawing a conclusion in the classical sense, but rather see these two projects as an extended outlook for further research in the field of German schools abroad. The first project is led by Julie A. Panagiotopoulou and will be the subject of Timo Neubert's dissertation project. It aims to reconstruct educational biographies of multilingual students in German schools abroad in Southern Europe, specifically Greece. The project focuses on experiences of inclusion/exclusion and (non-) belonging of "Greek" bi/multilingual students in the context of German schools of encounter (see Sect. 3.1). The second project is the doctoral research project of Janine Fißmer, supervised by Lisa Rosen. It focuses on professional biographies of teachers at German schools abroad that are characterized by mobility and internationality. The overarching question is to what extent the work experiences gained at German schools abroad will professionalize teachers in dealing with migration-related diversity and thus contribute to inclusive school development (see Sect. 3.2).

\section{$2 \quad$ Migration-Related Multilingualism and Pedagogical Professionalism}

\subsection{The Initial Research Project}

Within the framework of the international comparative project "Migration-related multilingualism and pedagogical professionalism" (the theoretical background, design and first results can be found in Panagiotopoulou and Rosen 2015b), the 
aim was to dwell on the practical experiences and those relating to the educational biography of pedagogical professionals in multilingually organized educational institutions in and outside Germany using expert interviews (Bogner and Menz 2009). The interview guide comprised eleven questions, some of which refer to the multilingual and translingual reality of multilingual children and adolescents both in the context of the educational institution as well as outside of it and prompted the pedagogical experts to share their views. Other questions invite the interviewees to comment on scientific findings and to focus on their own experiences as well as on the students multilingual practices at the German schools abroad in order to answer the following leading research question: "[i]f and how do the experiences gained by pedagogical professionals in multilingually organized educational settings interrelate with their views on migration-related multilingualism, linguistic diversity and language practices at school?" (Panagiotopoulou and Rosen 2015b, p. 230).

With respect to the research field of German schools abroad, it should first of all be noted that while these schools are private schools within their host countries, they are supervised and partially funded by the German state (Brüser-Sommer 2010) and follow one of the official German curricula from kindergarten to high school. These institutions are open to students from local, bi-national, expat and migrant families while maintaining strong ties to Germany and especially the German language. Teaching staff at these schools can be either locally recruited or temporarily dispatched teachers trained and tenured in Germany who keep their status as civil servants. Within the many German schools abroad across the globe, a distinction can be made between different school types: the two most important are Deutschsprachige Schulen [German-speaking schools] and Begegnungsschulen [schools of encounter]. In this second context, students may graduate with both national degrees and the German Abitur [highschool diploma]. While the official language of the host state is partly also the language of instruction in bilingual encounter schools, German is the sole language of instruction in German-speaking schools (Brüser-Sommer 2010).

First starting with German schools abroad in Greece and Canada and later on in the United States, a theoretical contention was that the views of pedagogical professionals regarding multilingualism and their interaction with the linguistic reality of multilingual children are always embedded socio-culturally and are therefore shaped by concrete values and concepts: according to Maitz (2014), these values can be understood "as assumptions and convictions that can be used to explain and justify linguistic facts and practices" (p.4), they relate to language ideologies that are mostly unconscious and rarely articulated as such. Instead, they are "located in metalinguistic statements" and hence can only be 
made accessible through "a qualitative analysis of authentic metalinguistic discourses" (Maitz 2014, p. 4). A comparative axis should therefore be established with the different fields of research in Southern Europe and North America, considering the negotiability of the language hierarchies in both regions: while Greek is assumed to increasingly lose its status as a dominant, official language, and German to gain a stronger, more dominant role in the context of the German schools in Greece (see Sect. 3.1), the sociopolitical value of the Francophonie in Québec and especially the asserted dominant position of French within the German school in Montreal is unlikely to be challenged by German as one of many heritage languages in Canada (see Sect. 2.2).

Using Grounded Theory according to Charmaz (2014), the analysis of selected interviews from the corpus-now encompassing 65 interviews from German schools abroad, which are currently being extensively analyzed in Jenna Strzykala's doctoral research (see Sect. 2.2) — has so far yielded a broad variety of views towards migration related multilingualism and heteroglossia (Bakhtin 1981) in educational settings. ${ }^{1}$ The findings hint at the following preliminary insights: Multilingual teachers in German schools abroad showcase a spectrum ranging from monoglossic to heteroglossic views when it comes to addressing multiple languages in their teaching practice. Even with multilingual teachers one cannot assume that their own linguistic reality and that of their students is being addressed in their daily school life. While some hold very dynamic views on bilingualism, others adhere to monoglossic (teaching) approaches, specifically:

- Some partially doubt the monolingual language policy of the German school as educational ideal and as didactical principle or they may contradict these offensively

- Some plead for a compensatory language training for non-native speakers or for multiple monolingual actions, in order to support the L2 language acquisition of multilingual children (Panagiotopoulou and Rosen 2015b, 2017)

\footnotetext{
${ }^{1}$ In addition to German schools abroad, complementary schools were also among the fields of research of the initial project "migration-related multilingualism and pedagogical professionalism" (on the methodology of international comparison and the different fields of research see Panagiotopoulou and Rosen 2015, p. 231f.). At the present time, we have conducted 21 interviews in Canada and the USA using the above-mentioned interview guide adapted to complementary schools. Results regarding the sampled complementary schools have already been published (see Panagiotopoulou et al. 2017; Panagiotopoulou and Rosen 2019).
} 
From this we developed the hypothesis that the (emerging) multilingualism of educators in the context of German schools abroad does not automatically lead to a simple appreciation of the multilingualism of students. Moreover, these teachers are beginning to question and distance themselves from the monolingual decree; some of them even implicitly adopt translanguaging at school (for translanguaging as a pedagogy, see García 2009; García and Li Wei 2014) by including and valorizing the family languages.

\subsection{Multilingual Teachers' Views on "Family", "National", and "Academic" Language(s) and Everyday Multilingual Practices of Staff and Students at German Schools in the USA and Canada}

Building on these first findings from the initial project as well as on its design is a doctoral dissertation focusing on a specific aspect of everyday school life at German schools abroad, namely Translanguaging as an everyday social practice of multilingual families, students and educators as coined by García (2009; see also García and Li Wei 2014).

This section presents the ongoing research on selected data gathered in the USA and Canada pertaining to the views on multilingualism in everyday school life of (multilingual) teachers at German schools abroad. This dissertation project shares a common research interest with the initial project, i.e., reconstructing underlying (language) ideologies and investigating their links to (implicit) institutional (language) policies. It focuses on the translanguaging strategiesself-reported, sometimes unconscious, often unacknowledged-that frame the everyday lives of multilingual teachers and students in German schools abroad, reconstructed through the views or beliefs of the interviewees, presuming that "all beliefs exist within a complex, interconnected and multidimensional system. Within that multidimensional system, beliefs may be primary or derivative (i.e., grounded in primary beliefs), core or peripheral (i.e., endorsed with more or less conviction) and be held in clusters, that are more or less isolated, thereby allowing incompatible or inconsistent beliefs to coexist" (Buehl and Beck 2015, p. 66). Thus, considering both the educators' own histories of migration, their professionalization and their own language ideologies on the one hand, and the reported or implied language policy of the institution they represent on the other hand, this project explores how they navigate their multilingual practices and how and to what extent translanguaging frames these practices within and outside of what one could argue is a German (educational) enclave. 
By focusing on German schools abroad in Canada and the USA, what becomes possible is a comparative approach working on two simultaneous axes:

- first, between extra-European German schools abroad as German educational enclaves and state schools in Germany (or what the interviewees report on their experiences with state schools in Germany)

- second, between two North American countries-the USA and Canada-as extra-European fields of action of the German school system, its (language) policies, and exposure to (migration-related) (linguistic) diversity

Especially the second axis is what adds novelty to the initial research project. As fields of comparison, Canada and the United States are intrinsically different when it comes to the social history and role of (European) migration and the contemporary (educational) value of multilingualism (and social diversity at large). Canada and especially Québec are historically multilingual, with French and English being official languages and very present in both English-language and French-language public education. Support for so-called heritage languages for migrants and their children is long-established in education policy (even if tension between policy and classroom reality do exist and are still pervasive (Breton-Carbonneau et al. 2012)). However, the United States' educational system serves an imagined monocultural, monolingual audience with very little acknowledgement for the (linguistic) needs of multilingual and migrant children (García 2009; Flores and García 2017). Considering these fundamental differences when it comes to the social and political status of (migration-related) multilingualism, German schools abroad, albeit private schools and hence only marginally impacted by national educational policies, are of particular interest here as they allow for an extra-European comparison of German educational enclaves. Furthermore and beyond their contextual and historic differences, Québec with its ever-strong Francophonie and its "French linguistic landscape" (Crump 2017, p. 155) following Bill 101 and the USA with its infamous History of bilingual education relegated to "racialized basements" (Flores and García 2017, p. 15) as extra-European fields share a non-negotiability of their respective dominant national language. In fact, as opposed to the marginalization of Greek in favor of the increasing dominance of German as observable in German schools in Greece (see Sect. 3.1 for a follow-up project focusing on language hierarchies in German schools in Greece), English and French respectively exist as strong competition with German in the USA and Québec and appear very unlikely to be challenged by the German language even within German schools. Considering 
these new particularities that come with the expansion of the research field into North America, the following research questions are to be answered:

- What role does German as "family", "national" and/or "academic" language play in a non-German-language dominated extra-European school context as opposed to its increasingly dominant role in Europe? When it comes to educators in German schools abroad, how do the German language and reported everyday multilingual practices impact the beliefs regarding multilingualism these educators hold?

- To what extent does translanguaging-as every day and/or pedagogical practice-appear in the educators' self-reports as a "natural" strategy for managing and synergizing the linguistic expectations of the German school abroad and those of the national context?

First results from the gathered interview data with educators in Boston and Montreal hint at various levels of conformity with as well as resistance to the perceived policy, with pedagogically intended and student-initiated (and tolerated) translingual time-spaces playing a major role in these multilingual settings, partly creating (with or without conscious attempts) what García et al. (2017) have called "translanguaging classrooms".

\section{$3 \quad$ Further Perspectives: Follow-up Projects}

\subsection{Between Exclusivity and Exclusion in the European South: Educational Biographies of Multilingual "Greek" Students in German Schools}

German schools abroad are considered to be exclusive educational institutions: They function mainly as private Begegnungsschulen-meaning schools that are supposed to facilitate an encounter and a dialogue between the respective "different cultures" (Federal Foreign Office 2019; Kultusministerkonferenz 2017)—for socioeconomically privileged (upper) middle class families from the host countries (Kühn and Mersch 2015). This is because German schools abroad promiseobviously based on the EU concept of plurilingualism (see below) - a German International High-School Diploma (DIA). According to the website of the German School in Thessaloniki (http://www.dst.gr/integrierte-begegnungsschule), this diploma grants access to universities in "virtually all European countries, the USA and other countries of the world". This assessment provides a characteristic 
example of the way the DIA is used for self-promotion in the case of German schools abroad, in Thessaloniki and elsewhere. In Greece, the aforementioned (upper) middle class families use these schools as a purposeful preparation for their children's "educational migration" triggered by the European financial crisis (Gkolfinopoulos and Panagiotopoulou 2020). From a German perspective, this serves as a recruitment strategy by the schools, which was elaborated by the KMK: through "German language promotion and binational school diploma" it is not only possible to win over those students who are "German" but also "young foreigners are prepared for economic contacts with Germany or respectively for academic studies in Germany" (KMK 2017, p. 3). As an instrument of recruitment, but also as a place of supposed intercultural encounter, these German schools abroad target Germans who work abroad on the one hand while, on the other hand, allegedly offering the opportunity to adolescents in the host countries to get to know the "German culture" and language (Kühn and Mersch 2015) and also to be plurilingual European citizens. In German schools abroad, the envisioned "dialogue between the cultures" (KMK 2017, p. 3) is therefore based on a simplistic idea of two separable national cultures (Radtke 2011) and on "named languages that represent different cultures and political states" (García and Otheguy 2019, p. 2). Following García and Otheguy (2019), it can be assumed that in German schools in Greece "raciolinguistic ideologies [...] operate even when practices follow a philosophy of plurilingualism". In addition, the expectation for students positioned as Greeks in German schools in Greece "is not that they speak and use the national [German] language 'to varying degrees' but to what is considered a 'native' norm" (p. 7). This in turn leads to the classification of children as "native German(-speaking)" versus "native non-German(-speaking)" from a young age when transitioning to German schools abroad. The questions how these ideologies correspond with the bi/multilingual students' and teacher's translanguaging practices and how the according ascriptions are processed in the students' educational biographies still remain empirically open.

The main prerequisite for education in exclusive schools like the German schools abroad is "a certain linguistic capital" (Bourdieu 2017, p. 126), which in Germany consists of the school-sanctioned (foreign) languages, i.e., the "languages of the former colonial powers and current privileged nation states" (Thoma 2018, p. 61). The empirical question concerning the possible implications of these exclusive and simultaneously exclusionary language policies for the educational biographies of students who speak languages that are considered "low-prestige (migrant) languages" in Germany remains equally pertinent in the global South. The evidence provided by research in "a German school abroad in postcolonial foreign countries" indicates an alarming shift in linguistic (power) 
relations, namely the delegitimization of the language(s) "of the native population" in favor of "a focus on the spread of the German language" (Paulus 2011, p. $27 \mathrm{f}$.). Since the "legitimate" language always functions as a means of distinction, thus facilitating the reproduction of inequalities (in school) (Bourdieu 2017), the issue addressed here concerns not only the global South but also the European South. Based on the existing internationally comparative groundwork in the North American and the Southern European regions investigating the views of teachers in German schools towards migration-related multilingualism (Panagiotopoulou and Rosen 2015b, 2017; see also Sect. 2.1), it was possible to reconstruct how ambivalent the German language policy is and, depending on the host country, to what extent it is oriented mono- or plurilingually. For instance, at the German school in Montreal, children are exposed to an elite "trilingualism" already in the school's kindergarten prior to their enrollment in primary school (see Panagiotopoulou 2017a), whereby German, which is considered an "immigrant language" in Canada (Statistics Canada/Census 2016), is valorized and thus added to the elite "linguistic trinity of German-French-English". By contrast, in the kindergarten of the German school in Athens, all "non-(monolingual) German-speaking" preschoolers are "consistently" taught in "German only" (Panagiotopoulou 2016, p. 18) to prepare them for the German primary and secondary schools characterized by that same strict language separation (Neubert 2018). These first research results imply that "foreign" or "domestic" adolescents who are living bi/multilingually by attending German schools abroad are faced with language hierarchies and language ideologies depending on the host country. Paulus (2011) points out that these schools' self-definition as German schools reflects a normative stance that causes not only the termination and prevention of domestic perspectives, but also the exclusion of certain behavioral patterns that are connected to the local culture. To what extent and how "translingual practices" (Canagarajah 2013), which are important locally (i.e., in the everyday life of bilingual "German-Greek" families), are excluded from everyday school life could be reconstructed through an ethnographical research approach. Glorius (2016) claims that the educational biographies generated by German schools abroad do not only involve gaining knowledge but also a "loss of capital" and sometimes lead to negatively connotated "either-or decisions" (p. 114). Regarding language use, the question thus arises whether students with Greek as a family language, labeled as a "low-prestige (migrant) language" in Germany, lose their own "linguistic capital" (Bourdieu 2017) by attending a German school in Greece. Furthermore, what remains to be seen is to what extent children and youths experience exclusion as well as being out of place through the course of their socialization in an exclusive school—as they are being addressed as 
"foreign", not-German and/or not-German-native speaking - and to what extent they see their own family languages (apart from German) as not relevant (anymore) for their own educational process.

From the perspective of pedagogical biographical research, it is important to address the impact such institutional contexts may have on individual educational processes of (emergent) bi/multilingual students, for instance to find out how young and older children use their entire linguistic repertoire to learn in class. Thereby, the project is focusing primarily not on the process of language acquisition, but rather on the process of self-positioning that adolescents perform (interactively) through their experiences of inclusion/exclusion as well as on the labelling processes with which students may be confronted in a school context that is influenced by the pervasive ideology of "native-speakerism" (Knappik and Dirim 2013). In detail: The project aims to reconstruct experiences of the participating "Greek" children-preschoolers aged 5 to 6 and primary school children aged 7 to 12 -with the school's monolingual and plurilingual policies by observing their practices and interactions with each other and their educators. Additionally, high schoolers who have graduated or are about to graduate with the German International High-School Diploma will be interviewed using biographic narrative interviews (see Thoma 2018). Thus, in order to exemplify educational biographies from kindergarten through high school, a quasi-longitudinal field research design is implemented in the context of one of the German schools abroad (not named here for anonymization purposes), using a research strategy which combines biographical and ethnographical approaches (Dausien and Kelle 2009; Schnitzer 2017; Panagiotopoulou 2017b).

\subsection{Transnational Professionalization for Schools in the Migration Society?}

In conjunction with the abovementioned the research project "Transnational Professionalization for Schools in the Migration Society?" focuses on the professional biographies of teachers who have gained work experience at German schools abroad. They are expected, and this will be initially discussed in the following, to contribute to inclusive school development in migration societies, similar to teachers with a so-called migration background.

A central consideration relates to institutionalized educational inequalities: Students with a so-called migration background are still disproportionately affected by these disparities in the German school system (Rosen 2019). In addition to the structural reform of the education system (Rosen 2018), models and 
strategies of inclusive school development are applied at the personnel level to the recruitment of teachers with transnational (professional) biographies (Panagiotopoulou and Rosen 2015a): For example, teachers with a so-called migration background are supposed to contribute to the reduction of educational disadvantage through "habitus sensitivity" (Fabel-Lamla and Klomfaß 2014). However, the positive impact of personal or familial migration experiences on pedagogical-professional competences in dealing with migration-related diversity, which is assumed in educational policy, must be questioned on the basis of exploratory studies (Lengyel and Rosen 2015; Panagiotopoulou and Rosen 2016; Rosen 2015). Similar to teachers with a so-called migrant background, teachers who worked at a German school abroad are also assumed to have specific competences in dealing with migration-related diversity, such as special pedagogical abilities in dealing with multilingualism, acquired through work experiences abroad. For example, one of the central educational policy documents states that they acquire "intercultural competences" (KMK 2017, p. 4). In addition, the document states as a goal for returning teachers that a field of activity should be found for them "in which they can optimally use and ideally expand their newly acquired skills in teaching practice, thus also contributing to school development at home" (KMK 2017 , p. 5). Furthermore, in the context of symposia organized jointly with educational researchers, in particular of the internationally and interculturally comparative educational sciences, the connection between "German school work abroad and intercultural socialization" is currently being deepened. ${ }^{2}$ However, on these occasions the quasi-automatism of "intercultural experiences towards intercultural competence" is relativized by the question of whether "returnees from school work abroad can contribute to the interculturality and internationality of schools in Germany" (p. 4), but still is made thematically relevant (Köhler-Fritsch 2018). In the empirical preliminary work within the above described project "Migrationrelated multilingualism and pedagogical professionalism", a certain potential of these experiences of (temporary) migration abroad could be reconstructed along the lines of views on migration-related multilingualism that teachers hold: The teachers at German schools abroad interviewed in the course of expert interviews expressed themselves in a diversity-conscious manner by questioning monolingual ideologies of the German school system and switching to translingual, i.e., teaching practices that include and valorize the family languages of their students (Panagiotopoulou and Rosen 2015b, 2017; see also Sect. 2.1). However, the

\footnotetext{
${ }^{2}$ see https://www.interedu.phil.fau.de/2019/03/27/tagung-deutsche-auslandsschularbeit-undinterkulturelle-sozialisation/.
} 
majority of German schools abroad has so far been regarded as a "blind spot" in educational research (Adick 2013, p. 109; Kühn and Mersch 2015, p. 198f.). In a systemization of existing studies the "subject area of returnees" has been identified as one of a total of three "overarching research topics" (Mägdefrau and Wolff 2018 , p. 6) and the question how "the competences of returnees can be used for school development processes at home" (p. 13) is outlined as a central strand of a research framework plan for German schools abroad (Mägdefrau and Wolff 2018, p. 6). This desideratum is taken up by the research project "Transnational Professionalization for Schools in the Migration Society?" and focuses on the question of professionalism of teachers addressing migration-related diversity through work experience at German schools abroad, more specifically through the acquisition of their own temporary migration experiences. Is there a difference between these teachers within the framework of an explorative research approach and the mainstream of teachers who often perceive the migration-related diversity of their students as a deficit and not as a resource (Auernheimer and Rosen 2017)? Do they see themselves as being habitualized and professionalized with regard to their students' diversity?

In order to investigate these initial questions, three research approaches will be selected and systematically triangulated (Flick 2004) in the course of the research process:

(1) Firstly, a document analysis (Wolff 2004) will be carried out to examine teachers" experiences abroad with regard to their (re)arrangements of the "self" and the "other". This analysis will investigate publications of the Central Agency for Schools Abroad (ZfA) and of the AGAL [Working Group of Teachers Abroad] of the GEW [Union Education and Science]. These publications are yearbooks (since 2004), the magazines "Begegnung" [encounter] (since 1980) and "TIP/TIPP-Theorie, Information, Praxis" [theory, information, practice] (until 2006) and newsletters. ${ }^{3}$ One guiding question will be whether and to what extent there are similarities and disparities between the reports of teachers at schools abroad within vs. outside the "Fortress Europe" (Bade 2016, p. 92) respectively in the "global South" vs. the "global North". These results are to be included in the choice of interview partners in the subsequent data collection and analysis stage.

(2) Secondly, biographical-narrative oriented interviews (Rosenthal and Fischer-Rosenthal 2004) are carried out to reconstruct the subjective views of teachers on migration-related diversity along their experiences of "being a

\footnotetext{
${ }^{3}$ see https://www.auslandsschulwesen.de/Webs/ZfA/DE/Services/Publikationen/publikationen_ node.html.
} 
stranger" and to conduct an intersectional analysis. According to the theoretical sampling in the course of the iterative or circular research process, approximately 12 teachers should be interviewed who

- have taught for at least three years at a German school in a European or non-European country,

- completed their schooling abroad at "schools of encounter" ("Begegnungsschulen”) (Kühn and Mersch 2015, p. 195) and taught a heterogeneous group of students

- have professional experience as teachers in Germany and

- whose stay abroad at the time of the interview dates back between two and five years.

(3) Teachers will be selected on the basis of maximally and minimally contrasting case studies from the second research step. Following an ethnographic approach (Lüders 2004), these teachers will then be accompanied in this third phase of the study in their everyday teaching practice. By means of participating observations, their routines in dealing with migration-related diversity in school and during lessons will be captured and reflected in feedback discussions. Specifically, the participants' estimations of whether school situations are linked to the gain in diversity awareness through their work abroad will be examined. Furthermore, it will be explored whether and to what extent they believe to "capitalize" on their employment abroad in terms of their teaching career.

\section{References}

Adick, C. (2013). Deutsche Auslandsschularbeit - Thema oder blinder Fleck in der Vergleichenden Erziehungswissenschaft? In Gewerkschaft Erziehung und Wissenschaft (Ed.), Transnationale Bildungsräume in der globalen Welt. Herausforderungen für die deutsche Auslandsschularbeit [Transnational educational areas in the globalized world. Challenges for the work of German schools abroad] (pp. 109-122).

Auernheimer, G., \& Rosen, L. (2017). Lehrer_innen-Schüler_innen-Interaktion in der Migrationsgesellschaft [Teacher-student interaction in the migration society]. In M. Schweer (Ed.), Lehrer-Schüler-Interaktion. Inhaltsfelder, Forschungsperspektiven und methodische Zugänge [Teacher-student interaction. Content fields, research perspectives and methodical approaches] (pp. 435-463). Wiesbaden: Springer VS.

Bade, K. (2016). Von Unworten zu Untaten. Kulturängste, Populismus und politische Feindbilder in der deutschen Migrations- und Asyldiskussion zwischen >Gastarbeiterfrage und >Flüchtlingskrise< [From wrong words to wrongdoings. Cultural fears, populism and enemy images in the German migration and asylum discussion between >guest worker question< and >refugee crisis $<$ ]. IMIS-Beiträge, 48, (35-171). 
Bakhtin, M. (1981). The Dialogic Imagination: Four Essays. Austin: University of Texas.

Bogner, A., \& Menz, W. (2009). The Theory-Generating Expert Interview: Epistemological Interest, Forms of Knowledge, Interaction. In A. Bogner, B. Littig \& W. Menz (Eds.), Interviewing Experts. Research Methods Series (pp. 43-80). London: Palgrave Macmillan.

Bourdieu, P. (2017). Sprache. Schriften zur Kultursoziologie 1 [Language. Writings on cultural sociology] (ed. by F. Schultheis \& St. Egger). Berlin: Suhrkamp.

Breton-Carbonneau, G., Cleghom, A., Evans, R., \& Pesco, D. (2012). Pedagogical and political encounters in linguistically and culturally diverse primary classrooms: examples from Quebec, Canada, and Gauteng, South Africa. Compare: A Journal of Comparative and International Education, 42 (3), (373-391).

Brüser-Sommer, E. (2010). Bund-Länder-Inspektionen im Rahmen des pädagogischen Qualitätsmanagements deutscher Schulen im Ausland: Struktur- und Wirkungsanalyse [national and federal inspection in the context of qualitiy management at German schools abroad: analysis of structure and effect] (Doctoral dissertation, Technische Universität Dortmund). Retrieved from https://d-nb.info/1009032011/34.

Buehl, M. M., \& Beck, J. S. (2015). The Relationship Between Teachers' Beliefs and Teachers' Practices. In H. Fives, \& M. G. Gill (Eds.), International Handbook of Research on Teachers' Beliefs (pp. 66-84). New York: Routledge.

Canagarajah, S. (2013). Translingual Practice: Global Englishes and Cosmopolitan Relations. London: Routledge.

Charmaz, K. (2014). Constructing grounded theory. Introducing qualitative methods. London: Sage.

Crump, A. (2017). "I speak all of the language!": Engaging in family language policy research with multilingual children in Montreal. In J. MacAlistar \& S. H. Mirvahedi (Eds.), Family language policies in a multilingual world: Opportunities, challenges, and consequences (pp. 154-174). London: Routledge.

Dausien, B., \& Kelle, H. (2009). Biographie und kulturelle Praxis. Methodologische Überlegungen zur Verknüpfung von Ethnographie und Biographieforschung [Biography and cultural practice. Methodological thoughts on the combination of ethnographic and biographic research]. In B. Völter, B. Dausien, H. Lutz \& G. Rosenthal (Eds.), Biographieforschung im Diskurs [Biographic research in discourse] (pp. 189-212). Wiesbaden: Springer VS.

Fabel-Lamla, M., \& Klomfaß, S. (2014). Lehrkräfte mit Migrationshintergrund. Habitussensibilität als bildungspolitische Erwartung und professionelle Selbstkonzepte [Habitus sensitivity as an expectation of educational policy and professional self-concepts]. In T. Sander (Ed.), Habitussensibilität [Sensitivity to habitus] (pp. 209-228). Wiesbaden: Springer VS.

Federal Foreign Office (2019). German schools abroad - where children from different cultures can meet and engage in dialogue. https://www.auswaertiges-amt.de/en/aussenpolitik/themen/kulturdialog/04-schulen/uebersicht/227654. Accessed: December 27, 2019.

Flick, U. (2004). Triangulation in Qualitative Research. In U. Flick, E. v. Kardorff \& I. Steinke (Eds.), A Companion to Qualitative Research (pp. 178-183). London: Sage.

Flores, N., \& García, O (2017). A Critical Review of Bilingual Education in the United States: From Basements and Pride to Boutiques and Profit. Annual Review of Applied Linguistics, 37, (14-29).

García, O. (2009). Bilingual education in the 21st century: A global perspective. Malden: Blackwell. 
García, O., \& Li Wei (2014). Translanguaging. Language, Bilingualism and Education. New York: Palgrave MacMillan.

García, O., Ibarra Johnson, S., \& Seltzer, K. (2017). The translanguaging classroom: Leveraging student bilingualism for learning. Philadelphia: Caslon.

García, O., \& Otheguy, R. (2019). Plurilingualism and translanguaging: commonalities and divergences. International Journal of Bilingual Education and Bilingualism, 23 (01), (17-35). https://doi.org/10.1080/13670050.2019.1598932.

Gkolfinopoulos, A., \& Panagiotopoulou, J. A. (2020). The role of education in the context of the new migration from Greece to Germany in times of financial crisis. [O rolos tis ekpaideusis sta plaisia tis metanasteusis apo tin Ellada pros ti Germania sta xronia tis krisis]. Greek Sociological Review, (7), (17-36), (in Greek).

Glorius, B. (2016). Transnationale Bildungs- und Mobilitätsbiographien von Absolventinnen und Absolventen Deutscher Auslandsschulen [Transnational educational and mobile biographies of graduates from German schools abroad]. In A. Tölle \& R. Wehrhan (Eds.), Translokalität und translokale Raumproduktionen in transnationaler Perspektive [Translocality and translocal space productions from a transnational perspective] (pp. 97-117). Berlin: Logos.

Knappik, M., \& Dirim, I. (2013). "Native Speakerism" in der Lehrerbildung. Journal für LehrerInnenbildung, 3, (20-23).

Köhler-Fritsch, I. (2018). Interkulturalität und Demokratie. Dokumentation zur 21. Fachtagung der GEW-Arbeitsgruppe Auslandslehrerinnen und Auslandslehrer und der Heimvolkshochschule Mariaspring 2016 [Interculturality and democracy. Documentation on the 21st conference of the GEW working group for teachers at schools abroad]. Gewerkschaft Erziehung und Wissenschaft. https://www.gew.de/index.php?eID=dump File $\& \mathrm{t}=\mathrm{f} \& \mathrm{f}=69230 \&$ token $=\mathrm{bf} 38 \mathrm{f} 3 \mathrm{~b} 587 \mathrm{f0d} 6 \mathrm{f} 89 \mathrm{c} 5663 \mathrm{f} 91 \mathrm{f} 160427 \mathrm{c} 2 \mathrm{~d} 7 \mathrm{ee} 20 \&$ sdownloa d=\&n=Doku_AGAL_Tagung_2016_WEB.pdf. Accessed: February 19, 2020.

Kühn, S. M., \& Mersch, S. (2015). Deutsche Schulen im Ausland: Strukturen - Herausforderungen - Forschungsperspektiven [German schools abroad: structures - challenges research perspectives]. DDS - Die Deutsche Schule, 107 (02), (193-202).

Kultusministerkonferenz (2017). [The Standing Conference of the Ministers of Education and Cultural Affairs of the Länder in the Federal Republic of Germany]. Einsatz deutscher Lehrkräfte im Auslandsschulwesen als ein Instrument der Personal- und Schulentwicklung der Länder [Deeployment of German teachers in schools abroad as an instrument of development of staff and schools of the federal states]. https://www. kmk.org/fileadmin/Dateien/veroeffentlichungen_beschluesse/2017/2017-10-12-EinsatzLK-ASW.pdf. Accessed: December 27, 2019.

Lengyel, D., \& Rosen, L. (2015). Diversity in the staff room - Ethnic minority student teachers' perspectives on the recruitment of minority teachers. Tertium Comparationis, 21 (02), (161-184).

Lüders, C. (2004). Field Observation and Ethnography. In U. Flick, E. v. Kardorff \& I. Steinke (Eds.), A Companion to Qualitative Research (pp. 222-230). London: Sage.

Maitz, P. (2014). Kann - soll - darf die Linguistik der Öffentlichkeit geben, was die Öffentlichkeit will? [Can - should - may linguistics give the public what the public wants?]. In T. Niehr (Ed.), Sprachwissenschaft und Sprachkritik. Perspektiven ihrer Vermittlung [Linguistics and language criticism. Perspectives of their mediation] (pp.9-26). Bremen: Hempen. 
Mägdefrau, J., \& Wolff, M. (2018). Deutsche Auslandsschularbeit im Spiegel der Forschung [German schools abroad as reflected in research]. https://www.gew.de/index. $\mathrm{php}$ ? ID $=$ dumpFile $\& \mathrm{t}=\mathrm{f} \& \mathrm{f}=68648 \&$ token $=4 \mathrm{ab} 336 \mathrm{c} 0 \mathrm{ea} 35 \mathrm{a} 6 \mathrm{~d} 563 \mathrm{a} 20 \mathrm{ef} 8 \mathrm{f} 8029 \mathrm{c} 809 \mathrm{e} 5$ c6d70\&sdownload=\&n=2018-04_MTS-Expertise_Auslandsschuldienst_im_Spiegel_ der_Forschung.pdf. Accessed: April 9, 2019.

Neubert, T. (2018). Monolinguale vs. mehrsprachige Alltags- und Unterrichtspraxis aus Sicht von Lehrpersonen an deutschen Schulen im Ausland [Monolinguals vs. multilingual everyday and teaching practice from the perspective of teachers at German schools abroad] (Unpublished master's thesis). University of Cologne, Germany.

Panagiotopoulou, A. (2016). Mehrsprachigkeit in der Kindheit: Perspektiven für die frühpädagogische Praxis [Multilingualism in Childhood: Perspectives for Early Childhood Pedagogy]. München: Deutsches Jugendinstitut e.V.

Panagiotopoulou, A. (2017a). Mehrsprachigkeit und Differenzherstellung in Einrichtungen frühkindlicher Erziehung und Bildung [Multilingualism and doing difference in institutions of early childhood education]. In I. Diehm, M. Kuhn \& C. Machold (Eds.), Differenz - Ungleichheit - Erziehungswissenschaft [Difference - Inequality - Educational Science] (pp. 257-274). Wiesbaden: Springer VS.

Panagiotopoulou, A. (2017b). Ethnographische Zugänge zur Erforschung von Mehrsprachigkeit [Ethnographic approaches to the study of multilingualism]. In M. Becker-Mrotzek \& H.-J. Roth (Eds.), Sprachliche Bildung - Grundlagen und Handlungsfelder [Linguistic education - basics and fields of action] (pp. 205-218). Münster: Waxmann.

Panagiotopoulou, A., \& Rosen, L. (2015a). Migration und Inklusion [Migration and inclusion]. In K. Reich, D. Asselhboven \& S. Kargl (Eds.), Eine inklusive Schule für alle: Das Modell der Inklusiven Universitätsschule Köln [An inclusive school for all: the model of the inclusive university school in Cologne] (pp. 158-167). Weinheim: Beltz Juventa.

Panagiotopoulou, A. \& Rosen, L. (2015b). Professionalism and multilingualism in Greece and Canada: An international comparison of (minority) teachers' views on linguistic diversity and language practices in monolingual vs. multilingual educational systems. Tertium Comparationis, 21 (02), (225-250).

Panagiotopoulou, A., \& Rosen, L. (2017). Sichtweisen auf Mehrsprachigkeit von (migrationsbedingt) mehrsprachigen Lehrkräften - Ergebnisse einer international vergleichenden Studie [Perspectives on multilingualism of (due to migration) multilingual teachers - results of an international comparative study]. In M. Oberlechner, C. Trueltzsch-Wijnen \& P. Duval (Eds.), Migration bildet. Migration Educates (pp. 159-177). Baden-Baden: Nomos.

Panagiotopoulou, A., Rosen, L., \& García, O. (2017). Language Teachers' Ideologies in a Complementary Greek School in Montreal - Heteroglossia and Teaching. In P. Trifonas, \& T. Aravossitas (Eds.), Handbook of Research and Practice in Heritage Language Education (pp. 1-16). Wiesbaden: Springer VS.

Panagiotopoulou, A., \& Rosen, L. (2016). Sprachen werden benutzt, ,um sich auch gewissermaßen abzugrenzen von anderen Menschen“. Lehramtsstudierende mit Migrationshintergrund plädieren für einsprachiges Handeln im schulischen Kontext [Languages are used „to differentiate yourself from other people“. Prospective teachers with a migration background advocate monolingual action in a school context]. In T. Geier \& K. U. Zaborowski (Eds.), Migration: Auflösungen und Grenzziehungen - Perspektiven 
einer erziehungswissenschaftlichen Migrationsforschung [Migration: Resolutions and Drawing Boundaries - Perspectives of Educational Migration Research] (pp. 169-190). Wiesbaden: Springer VS.

Panagiotopoulou, J. A., \& Rosen, L. (2019). Recently Arrived Migrants as Teachers in Greek Complementary Schools in Montreal: Views on Multilingualism. In J. A. Panagiotopoulou, L. Rosen, C. Kirsch \& A. Chatzidaki (Eds.), 'New' Migration of Families from Greece to Europe and Canada: A 'New' Challenge for Education? (pp. 221-235). Wiesbaden: Springer VS.

Paulus, C. (2011). "Begegnung findet eigentlich nicht statt." Probleme von Begegnungsschulen im postkolonialen Kontext ["Actually there is no encounter." Problems of encounter schools in the post-colonial context]. Zeitschrift für internationale Bildungsforschung und Entwicklungspädagogik, 34 (02), (24-29).

Radtke, F.-O. (2011). Kulturen sprechen nicht. Die Politik grenzüberschreitender Dialoge [Cultures do not speak. The policy of cross-border dialogues]. Hamburg: Hamburger Edition.

Rosen, L. (2015). Abbau von Bildungsungleichheiten: Die bildungspolitische Forschung nach Vielfalt im LehrerInnenzimmer aus Sicht von Lehramtsstudierenden mit Migrationshintergrund [Reducing educational inequalities: Educational policy research on diversity in the teacher's room from the perspective of teaching students with a migration background]. In Y. Bulut \& H. Schwenk (Eds.), Identität und Bildungsbe(nach) teiligung in Deutschland [Identity and educational participation and discrimination in Germany] (pp. 73-94). Berlin: LIT.

Rosen, L. (2018). Schule und Schulmodelle in der Migrationsgesellschaft [Schools and school models in the migration society]. In I. Gogolin, V. B. Georgi, M. Krüger-Potratz, D. Lengyel \& U. Sandfuchs (Eds.), Handbuch Interkulturelle Pädagogik [Handbook Intercultural Pedagogy] (pp. 343-349). Bad Heilbrunn: Klinkhardt.

Rosen, L. (2019). Dauerhafte Ungleichheiten in den Schulen der Migrationsgesellschaften [Persistent inequalities in the schools of migrant societies]. Neue Gesellschaft - Frankfurter Hefte, 66 (7/8), (39-42).

Rosenthal, G., \& Fischer-Rosenthal, W. (2004). The Analysis of Narrative-biographical Interviews. In U. Flick, E. v. Kardorff \& I. Steinke (Eds.), A Companion to Qualitative Research (pp. 259-265). London: Sage.

Schnitzer, A. (2017). Mehrsprachigkeit als soziale Praxis. (Re-)Konstruktionen von Differenz und Zugehörigkeit unter Jugendlichen im mehrsprachigen Kontext [Multilingualism as a social practice. (Re-)constructions of difference and belonging among young people in a multilingual context]. Weinheim: Beltz Juventa.

Statistics Canada/Census (2016). Linguistic diversity and multilingualism in Canadian homes. https://www12.statcan.gc.ca/census-recensement/2016/as-sa/98-200x/2016010/98-200-x2016010-eng.cfm. Accessed: April 12, 2019.

Thoma, N. (2018). Sprachbiographien in der Migrationsgesellschaft. Eine rekonstruktive Studie zu Bildungsverläufen von Germanistikstudent*innen [Language biographies in the migration society. A reconstructive study of the educational pathways of students of German studies]. Bielefeld: transcript.

Wolff, S. (2004). Analysis of Documents and Records. In U. Flick, E. v. Kardorff \& I. Steinke (Eds.), A Companion to Qualitative Research (pp. 284-289). London: Sage. 
Open Access This chapter is licensed under the terms of the Creative Commons Attribution 4.0 International License (http://creativecommons.org/licenses/by/4.0/), which permits use, sharing, adaptation, distribution and reproduction in any medium or format, as long as you give appropriate credit to the original author(s) and the source, provide a link to the Creative Commons license and indicate if changes were made.

The images or other third party material in this chapter are included in the chapter's Creative Commons license, unless indicated otherwise in a credit line to the material. If material is not included in the chapter's Creative Commons license and your intended use is not permitted by statutory regulation or exceeds the permitted use, you will need to obtain permission directly from the copyright holder.

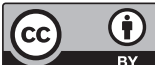

